УДК 342.9

DOI https://doi.org/10.32844/2618-1258.2019.6.24

БРУСАКОВА О.В.

\title{
ДЕРЖАВНЕ РЕГУЛЮВАННЯ ВИКОРИСТАННЯ ПОВІТРЯНОГО ПРОСТОРУ УКРАЇНИ
}

У статті наголошено на важливості визначення поняття та змісту державного регулювання використання повітряного простору України. Автор визначив концепцію «державного регулювання використання повітряного простору України». Автор визначив державне регулювання використання повітряного простору як діяльність уповноважених осіб, яку вони здійснюють у зв'язку з польотами літальних апаратів, переміщенням (перебуванням) матеріальних об'єктів у повітряному просторі України, здійсненням ряду інших робіт, та діяльність, пов'язану 3 використанням повітряного простору, шляхом впровадження набору передбачених законом засобів забезпечення безпеки авіації, забезпечення інтересів держави, національної безпеки та потреб суспільства та економіки в операціях 3 повітряного руху. Основними заходами, за допомогою яких здійснюється державне регулювання використання повітряного простору, є надання дозволів, умов, заборон та обмежень щодо використання повітряного простору; налагодження структури повітряного простору; консолідація маршрутів обслуговування повітряного руху; впровадження класифікації повітряного простору; планування та координація використання повітряного простору; розгляд заявок на використання повітряного простору; координація діяльності, пов'язаної з повітряним простором, і цивільно-військова координація; визначення порядку перетину повітряних суден державного кордону та використання повітряного простору місцевості із спеціальним режимом використання повітряного простору; здійснення контролю за дотриманням правил та правил використання повітряного простору України. Проаналізовано нормативно-правові акти, на рівні яких закріплено правові основи здійснення державного регулювання використання повітряного простору України з урахуванням їх юридичної сили. Нормативною основою для здійснення цих заходів державного регулювання використання повітряного простору є значна кількість нормативно-правових актів: Конституція України, міжнародні договори України, акти кодифікованого законодавства та закони України, підзаконні акти та положення. Серед останніх - нормативні акти, які були прийняті спільно Державною авіаційною службою та Міністерством оборони України.

Ключові слова: державне регулювання, правові засади, правове регулювання, повітряний простір України.

In the article it has been emphasized the importance of defining the concept and content of the state regulation of the use of Ukrainian airspace. The author has defined the concept of "state regulation of the use of Ukrainian airspace". The author has defined the state regulation of the use of airspace as the activity of authorized entities, which they perform in connection with flights of aircraft, the movement (stay) of material objects in the airspace of Ukraine, the implementation of a number of other works and activities related to the use of airspace, through the implementation of a set of statutory means to guarantee the safety of aviation, ensure the interests of the state, national security and the needs of society and economy in the air and air traffic operations. The main measures by which state regulation of the use of airspace is carried out are the granting of permits, conditions, prohibitions and restrictions on the use of airspace; establishment of airspace structure; consolidation of air traffic service routes; implementation of airspace classification; planning and coordinating the use of airspace; consideration of applications

() БРУСАКОВА О.В. - кандидат філософських наук, декан факультету № 6 (Харківський національний університет внутрішніх справ) 
for the use of airspace; coordination of airspace-related activities and civilian-military coordination; determining the procedure for crossing the state border aircraft and using the airspace of an area with a special regime of airspace use; exercising control over the observance of the rules and rules for the use of Ukrainian airspace. It has been analyzed the normative-legal acts, at the level of which the legal bases of realization of state regulation of the use of Ukrainian airspace are fixed, taking into account their legal force. The normative basis for the implementation of these measures of state regulation of the use of airspace is a considerable number of legal acts: the Constitution of Ukraine, international treaties of Ukraine, acts of codified legislation and laws of Ukraine, by-laws and regulations. Among the latter are the normative acts, which were adopted jointly by the State Aviation Service and the Ministry of Defense of Ukraine.

Key words: state regulation, legal principles, legal regulation, airspace of Ukraine.

Вступ. Одним із ключових аспектів функціонування авіаційної галузі є використання повітряного простору. Реалізація майже всіх суспільних відносин у авіаційній галузі так чи інакше пов'язана з використанням такого простору. Саме тому особливого значення набуває діяльність компетентних суб'єктів зі здійснення державного регулювання окресленої сфери суспільних відносин. Як було з'ясовано раніше, державне регулювання відповідних суспільних відносин $є$ доволі складною та багатоаспектною діяльністю, що здійснюється значною кількістю уповноважених державою суб'єктів шляхом використання найрізноманітніших засобів регулювання таких відносин задля підтримання iï функціонування в нормальному стані. 3 огляду на те, що використання повітряного простору України пов'язано як з діяльністю вітчизняних, так і зарубіжних суб'єктів авіаційної галузі, повітряний рух авіаційного транспорту, перевезення багажу, вантажів і пасажирів та багато інших аспектів здійснення державного регулювання цієї сфери суспільних відносин базується на значній кількості нормативно-правових актів.

Аналіз публікацій, в яких започатковано розв'язання проблеми. Предметом наукових пошуків поняття, сутність та зміст державного, в тому числі й адміністративно-правового, регулювання виступали в працях таких учених-правознавців: В.Б. Авер'янов, А.П. Альохін, Д.М. Бахрах, О.І. Безпалова, Ю.П. Битяк, І.П. Голосніченко, С.В. Ківалов, В.К. Колпаков, Т.А. Лагковська, В.Я. Малиновський, В.Б. Пчелін, В.П. Тимощук, М.К. Якимчук та інші. Проведені зазначеними вченими наукові дослідження мають велике теоретичне й практичне значення як в аспекті визначення категорії «державне регулювання», так і в аспекті встановлення сутності та змісту по відношенню до окремих сфер суспільних відносин. Разом із тим доводиться констатувати, що саме визначенню сутності та змісту державного регулювання використання повітряного простору України увага майже не приділялася, а стрімке оновлення чинного національного законодавства, що регулює цю сферу суспільних правовідносин, зумовлює здійснення додаткових наукових пошуків і визначає актуальність обраної тематики.

Постановка завдання. Тому мета представленої статті полягає у визначенні сутності та змісту державного регулювання використання повітряного простору України.

Результати дослідження. Як цілком слушно зауважує С.А. Матійко, нормативно-правова база як основа державного регулювання транспортної діяльності повинна забезпечувати ефективну взаємодію підприємств транспорту, державний захист прав споживачів транспортних послуг, безпеку транспортного процесу й охорону навколишнього середовища [1, с. 133]. Не є в цьому аспекті винятком і діяльність зі здійснення державного регулювання використання повітряного простору, що з огляду на багатоаспектність даних суспільних відносин зачіпає всі з названих вченим аспектів функціонування транспорту в найбільшому ступені порівняно з іншими галузями (автомобільного, залізничного, трубопровідного тощо транспорту). Саме тому першорядне значення серед нормативно-правових актів, на основі яких здійснюється державне регулювання використання повітряного простору, становить Основний Закон України [2], положення якого: закріплюють принципи здійснення такого регулювання; визначають основи правового статусу окремих з суб'єктів такої діяльності; $є$ правовим підгрунтям для всього іншого законодавства.

3 огляду на те, що використання повітряного простору України здійснюється значною кількістю зарубіжних суб'єктів авіаційної діяльності, особливого значення в аспекті здійснення державного регулювання даної галузі суспільних відносин набувають міжнародні правові стандарти, які знайшли свою об'єктивізацію в положеннях відповідного міжнародного договору України. Із цього приводу справедливою виглядає позиція щодо того, що нормативні правові акти, які регламентують діяльність видів транспорту, повинні розроблятися в їх гармонізації 
3 міжнародними правовими документами [1, с. 133]. Тобто міжнародні договори України слід розглядати як основу для прийняття національних нормативно-правових актів з питань здійснення державного регулювання використання повітряного простору України. Передусім серед таких міжнародних правових актів слід назвати Конвенцію про міжнародну цивільну авіацію від 7 грудня 1944 року, яка визначає такі аспекти здійснення державного регулювання використання повітряного простору: Договірні держави визнають, що кожна держава володіє повним і винятковим суверенітетом над повітряним простором над своєю територією (ст. 1); під територією держави розуміються сухопутні території та прилеглі до них територіальні води, які знаходяться під суверенітетом, сюзеренітетом, протекторатом або мандатом даної держави (ст. 2); у передбачених випадках кожна Договірна держава зобов'язується не дозволяти діяльність авіапідприємств будь-якої Договірної держави в повітряному просторі над своєю територією (ст. 87); визначає сутність міжнародного повітряного сполучення як повітряного сполучення, здійснюване через повітряний простір над територією більше ніж однієї держави; тощо [3].

При цьому особливого значення набувають додатки (всього 18) до Конвенції про міжнародну цивільну авіацію, серед яких у контексті здійснення державного регулювання використання повітряного простору України необхідно виділити: Додаток 2 «Правила польотів», який містить тільки стандарти та не містить рекомендовану практику та Додаток 11 «Обслуговування повітряного руху», в якому наголошено на тому, що сьогодні управління повітряним рухом, польотна інформація та служби оповіщення, які разом утворюють те, що називається обслуговуванням повітряного руху, є одними з найбільш важливих складових елементів серед обов'язкових наземних засобів забезпечення, необхідних для безпечного й ефективного здійснення повітряного руху по всьому світу. При цьому світовий повітряний простір розділений на ряд прилеглих один до одного районів польотної інформації, в межах яких забезпечується обслуговування повітряного руху. Головною метою обслуговування повітряного руху, як визначено в додатку, $є$ запобігання зіткнень повітряних суден на всіх етапах їх руху, будь то рулювання, зліт, посадка, політ на маршруті або за схемою очікування в аеропорту призначення [4].

Державне регулювання використання повітряного простору України здійснюється з урахуванням положень ще ряду міжнародних правових актів: Угода про цивільну авіацію та про використання повітряного простору від 25 грудня 1991 року, якою передбачено, що Договірні держави визнають, що кожна держава має повний і винятковий суверенітет над повітряним простором, над своєю сухопутною та водною територією; Договір з відкритого неба від 24 березня 1992 року; Багатостороння угода про сплату маршрутних зборів від 12 лютого 1981 року; Конвенція про відкрите море від 29 квітня 1958 року; Міжнародна конвенція щодо співробітництва в галузі безпеки аеронавігації «Євроконтроль» від 13 грудня 1960 року.

Наступну групу нормативно-правових актів, на основі яких здійснюється державне регулювання використання повітряного простору України, становлять закони України, в тому числі акти кодифікованого законодавства. Насамперед серед таких нормативно-правових актів слід назвати Повітряний кодекс України від 19 травня 2011 року, з аналізу преамбули якого слідує, що метою державного регулювання використання повітряного простору України є гарантування безпеки авіації, забезпечення інтересів держави, національної безпеки та потреб суспільства й економіки в повітряних перевезеннях та авіаційних роботах [5]. Також слід відмітити, що два розділи вказаного нормативно-правового акта повністю присвячено питанням, пов'язаним із використанням повітряного простору та здійсненням державного регулювання цієї діяльності. Так, аналіз Розділу II «Система державного регулювання в галузі авіації та використання повітряного простору України» свідчить про те, що державне регулювання використання повітряного простору здійснюється шляхом: визначення правового статусу суб'єктів даної діяльності; закріплення правил поведінки користувачів повітряного простору та відповідальності за їх порушення; здійснення державного контролю за такою поведінкою. Усі з наведених аспектів державного регулювання використання повітряного простору знаходять своє закріплення в положеннях відповідних нормативно-правових актів, зокрема тих, що затверджують численні авіаційні правила України.

На складність і багатоаспектність суспільних відносин з приводу державного регулювання використання повітряного простору вказує аналіз Розділу IV «Використання повітряного простору» Повітряного кодексу України. Так, вищенаведені законодавчі положення визначають наступні аспекти державного регулювання досліджуваної сфери суспільних відносин: сутність і складники організації використання повітряного простору; державні пріоритети у використанні повітряного простору України; повноваження державних органів, відповідальних за здійснення державного регулювання повітряного простору України; правовий статус об'єднаної цивіль- 
но-військової системи організації повітряного руху; структуру та класифікацію повітряного простору України; дозволи, заборони й обмеження в сфері використання повітряного простору України; здійснення контролю за дотриманням порядку та правил використання повітряного простору України; засади використання міжнародного повітряного простору та порядок перетинання повітряними суднами державного кордону України; обслуговування повітряного руху й управління повітряним рухом; порядок обслуговування аеронавігаційною інформацією та засади метеорологічного обслуговування [5].

Окрім вищенаведеного, до актів кодифікованого законодавства, положення якого визначають правові засади державного регулювання використання повітряного простору України слід віднести: Митний кодекс України від 13 березня 2012 року; Податковий кодекс України від 2 грудня 2010 року; Кримінальний кодекс України від 5 квітня 2001 року; Кодекс України про адміністративні правопорушення від 7 грудня 1984 року; тощо. Також правові засади державного регулювання використання повітряного простору України закріплено в численних законах України, серед яких слід назвати такі: закон України «Про Державну програму авіаційної безпеки цивільної авіації» від 12 березня 2017 року; закон України «Про прикордонний контроль» від 5 листопада 2009 року; закон України «Про державний кордон України» від 4 листопада 1991 року; закон України «Про охорону навколишнього природного середовища» від 25 червня 1991 року; закон України «Про охорону атмосферного повітря» від 16 жовтня 1992 року; тощо.

Особливе місце серед актів, що визначають правові засади державного регулювання використання повітряного простору України, посідають підзаконні нормативно-правові акти. Наводячи переваги цього рівня нормативної регламентації відповідної сфери суспільних відносин, В.Б. Пчелін цілком слушно підкреслює той факт, що рамки законів України не повною мірі дозволяють передбачити весь комплекс ситуацій, які в подальшому можуть підлягати такій регламентації. Ось чому, наголошує вчений, законодавством передбачена можливість самостійного регулювання суспільних відносин уповноваженими державою суб'єктами за допомогою видання підзаконного нормативно-правового акта, що дозволяє, наприклад, оперативно визначити компетенцію суб'єктів державного управління, закріпити права й обов'язки особи в межах відповідних суспільних відносин [6, с. 18].

Так, передусім серед вказаних актів слід назвати ті, що приймаються Президентом України. Зокрема, указом Президента України «Про заходи щодо забезпечення безпеки повітряного транспорту України» від 20 серпня 1992 року № 428/92 з метою забезпечення безпеки повітряного транспорту України, підвищення надійності авіаційної техніки та її конкурентоспроможності на світовому ринку було затверджено повноважних представників України в Раді держав - учасниць Угоди про цивільну авіацію та про використання повітряного простору [7]. Указом Президента України «Про затвердження військово-адміністративного поділу території України» від 5 лютого 2016 року № 39/2016 визначено, що повітряний простір України поділяється на чотири військово-повітряні зони та один окремий військово-повітряний район, межами яких $є$ умовні вертикальні поверхні, що проходять по лінії державного кордону України на суші, морі, річках, озерах, інших водоймах та по прямих лініях між визначеними географічними точками з урахуванням повітряного простору над тимчасово окупованою територією України [8]. Указом Президента України від 10 квітня 2019 року № 117/2019 було затверджено Річну національну програму під егідою Комісії Україна - НАТО на 2019 рік, ціллю 2.2.6 якої є вдосконалення співробітництва з НАТО в галузі організації повітряного руху та безпеки використання повітряного простору [9].

Окремо слід відмітити, що актами Президента України вводяться в дію рішення РНБО 3 питань здійснення державного регулювання повітряного простору, прикладом чого може служити: указ Президента України від 15 травня 2017 року № 133/2017, яким введено в дію рішення РНБО «Про застосування персональних спеціальних економічних та інших обмежувальних заходів (санкцій)» від 28 квітня 2017 року, яким окремим особам було заборонено використовувати повітряний простір України; тощо.

Особливе місце серед підзаконних нормативно-правових актів, положення яких визначають особливості державного регулювання використання повітряного простору України, посідають акти Кабінету Міністрів України. Так, відповідно до ч. 1 ст. 23 Повітряного кодексу України саме Кабінет Міністрів України затверджує Положення про використання повітряного простору України [5]. Це Положення затверджено постановою Кабінету Міністрів України від 6 грудня 2017 року № 954. Аналіз положень вищенаведеного нормативно-правового акта свідчить про те, що державне регулювання використання повітряного простору України здійснюється компетентними суб'єктами шляхом: погодження з органами місцевого самоврядування, суб'єктами 
авіаційної діяльності та затвердження інструкцій з використання повітряного простору на окремих категоріях місцевості; планування та координації діяльності з використання повітряного простору; надання дозволу або встановлення заборон виконання польотів; надання дозволу або встановлення заборон та обмежень на використання повітряного простору; менеджменту повітряного простору України та цивільно-військової координації під час організації повітряного руху; контролю за дотриманням порядку та правил використання повітряного простору України; обслуговування (диспетчерське, польотно-інформаційне, аварійне) повітряного руху; встановлення особливостей перетинання повітряними суднами державного кордону та польотів в зоні із особливим режимом використання повітряного простору; тощо [10]. При цьому, як слідує з аналізу вищенаведеного нормативно-правового акта, значні повноваження щодо здійснення державного регулювання використання повітряного простору України мають окремі центральні органи виконавчої влади й органи об'єднаної цивільно-військової системи організації повітряного руху.

Серед актів центральних органів виконавчої влади, на основі яких здійснюється державне регулювання використання повітряного простору, слід назвати ті, що приймаються Мінінфраструктурою, Міністерством оборони України та Державіаслужбою. Так, сьогодні кількість нормативно-правових актів, прийнятих Мінінфраструктурою, сягає більше ста, з огляду на що як приклад назвемо основні акти цього центрального органу виконавчої влади, на основі положень яких здійснюється державне регулювання використання повітряного простору: наказ Мінінфраструктури від 10 грудня 2013 року № 1009, яким затверджено Класифікацію повітряного простору обслуговування повітряного руху України; наказ Мінінфраструктури від 4 червня 2019 року № 415, яким затверджено Ставки плати за послуги з аеронавігаційного обслуговування повітряних суден у повітряному просторі України; наказ Міністерства транспорту та зв'язку від 23 червня 2010 року № 383, яким затверджено Правила обслуговування повітряного руху на цивільних аеродромах України; тощо. Акти Міністерства оборони встановлюють правові засади державного регулювання використання повітряного простору державною авіацією. Наприклад, серед таких актів слід назвати такі: наказ Міністерства оборони України від 9 грудня 2015 року № 700, яким затверджено Правила польотів державної авіації в повітряному просторі України; наказ Міністерства оборони України від 29 вересня 2015 року № 516, яким затверджено Правила метеорологічного забезпечення польотів державної авіації України; тощо. Окремі аспекти здійснення державного регулювання використання повітряного простору України визначено в підзаконних нормативно-правових актах, які було прийнято спільно Міністерством оборони України та Мінінфраструктури. Прикладом таких нормативно-правових актів можуть бути такі: спільний наказ Міністерства транспорту України та Міністерства оборони України від 27 січня 2003 року № 50/18, яким затверджено Інструкцію про розслідування порушень порядку використання повітряного простору України; спільний наказ Міністерства оборони України і Міністерства транспорту та зв’язку України від 14 жовтня 2009 року № 518/1063, яким затверджено Інструкцію зі складання заявок на використання повітряного простору під час планування проведення відповідного виду діяльності; тощо.

Найчисельнішу групу підзаконних нормативно-правових актів, положення яких визначають особливості державного регулювання використання повітряного простору, складають ті, що були прийняті Державіаслужбою. При цьому слід відмітити, що основоположні авіаційні правила України, які визначають особливості державного регулювання використання повітряного простору України, затверджено спільними наказами Державіаслужби та Міністерства оборони України. Так, порядок виконання польотів цивільних і державних повітряних суден, порядок обслуговування повітряного руху, порядок управління повітряним рухом, що гарантують безпеку польотів під час використання повітряного простору України та повітряного простору над відкритим морем, де відповідальність за обслуговування повітряного руху міжнародними договорами України покладено на Україну, цивільною та державною авіацією визначено в Авіаційних правилах України «Загальні правила польотів у повітряному просторі України», які затверджено спільним наказом Державіаслужби та Міністерства оборони України від 6 лютого 2017 року № 66/73 [11]. Безпосередньо вимоги щодо організації та порядку використання повітряного простору України користувачами повітряного простору визначено в Авіаційних правилах України «Правила використання повітряного простору України», що затверджені спільним наказом Державіаслужби та Міністерства оборони України від 11 травня 2018 року № 430/210.

Варто зазначити, що реалізацію майже всіх з наведених заходів державного регулювання використання повітряного простору України покладено на органи об'єднаної цивільно-військової системи організації повітряного руху України (далі - об’єднана система). Так, відповідно до 
Положення «Про об’єднану цивільно-військову систему організації повітряного руху України» об'єднана система складається 3 підрозділів, повноваження та діяльність яких пов'язані з організацією повітряного руху в повітряному просторі України й у міжнародному повітряному просторі, що перебуває під відповідальністю України. При цьому вказані підрозділи входять до складу Державного підприємства обслуговування повітряного руху України [12]. Відповідно до наказу Мінінфраструктури від 18 грудня 2018 року № 641, яким затверджено політику власності Державного підприємства обслуговування повітряного руху України, вказане підприємство $є$ державним комерційним підприємством, яке засноване на державній власності та належить до сфери управління Мінінфраструктури [13]. При цьому Державним підприємством обслуговування повітряного руху України $є$ Украерорух. Головним оперативним підрозділом об'єднаної системи $є$ Український центр планування використання повітряного простору України - Украероцентр, який входить до складу Украероруху [13]. Із цього слідує, що безпосереднє державне регулювання використання повітряного простору України здійснюють Украерорух та Украероцентр за допомогою передбачених законодавством засобів. Такі засоби, які в своїй сукупності утворюють методи державного регулювання використання повітряного простору, з огляду на важливість цього питання будуть розглянуті нами в межах окремого підрозділу представленого наукового дослідження.

Висновки. Отже, державне регулювання використання повітряного простору є діяльністю уповноважених суб'єктів, що здійснюється ними з приводу польотів повітряних суден, переміщення (перебування) матеріальних об'єктів у повітряному просторі України, здійснення ряду інших робіт і діяльності, пов'язаної з використанням повітряного простору, шляхом реалізації комплексу законодавчо закріплених засобів задля гарантування безпеки авіації, забезпечення інтересів держави, національної безпеки та потреб суспільства й економіки в повітряних перевезеннях та авіаційних роботах. Серед основних заходів, за допомогою яких здійснюється державне регулювання використання повітряного простору, слід назвати надання дозволів, встановлення умов, заборон і обмежень щодо використання повітряного простору; встановлення структури повітряного простору; закріплення маршрутів обслуговування повітряного руху; здійснення класифікації повітряного простору; планування та координації використання повітряного простору; розгляд заявок на використання повітряного простору; координацію діяльності, пов'язаної з використанням повітряного простору, та цивільно-військову координацію; визначення порядку перетинання повітряними суднами державного кордону та використання повітряного простору зони з особливим режимом використання повітряного простору; здійснення контролю за дотриманням порядку та правил використання повітряного простору України. Нормативну основу реалізації вказаних заходів державного регулювання використання повітряного простору становить значна кількість нормативно-правових актів: Конституція України, міжнародні договори України, акти кодифікованого законодавства та закони України, підзаконні нормативно-правові акти. Серед останніх особливе місце посідають нормативно-правові акти, що було прийнято спільно Державіаслужбою та Міністерством оборони України. Завдання із безпосереднього державного регулювання використання повітряного простору України покладено на Украерорух та Украероцентр.

\section{Список використаних джерел:}

1. Матійко С.А. Напрями вдосконалення законодавчої бази у сфері регулювання розвитку транспортної системи. Економіка та держава. 2010. № 10. С. 133-135.

2. Конституція України: Закон України від 28.06.1996 № 254к/96 ВР. Відомості Верховної Ради України. 1996. № 30. Ст. 141.

3. Конвенція про міжнародну цивільну авіацію 1944 р.: міжнародний документ від 07.12.1944. Офічійний вісник України. 2004. № 40. Ст. 2667.

4. Опис додатків до Конвенції про міжнародну цивільну авіацію 1944 р.: інформаційний документ від 02.11.2006. База даних «Законодавство України» Верховна Рада України. URL: https://zakon.rada.gov.ua/laws/show/995_655.

5. Повітряний кодекс України: Закон України: від 19 трав. 2011 р. № 3393-VI. Відомості Верховної Ради України. 2011. № 48-49. Ст. 536.

6. Пчелін В.Б. Перегляд адміністративних актів органів внутрішніх справ : дис. ... кандидата юрид. наук : спец. 12.00.07. Харків, 2011. 190 с.

7. Про заходи щодо забезпечення безпеки повітряного транспорту України: указ Президента України від 20.08.1992 № 428/92. Збірник указів Президента України. 1992. № 3. 
8. Про затвердження військово-адміністративного поділу території України : указ Президента України від 05.02.2016 № 39/2006. Офіційний вісник Украӥни. 2016. № 12. Ст. 500.

9. Про Річну національну програму під егідою Комісії Україна - НАТО на 2019 рік: указ Президента України від 10.04.2019 № 117/2019. Офіційний вісник України. 2019. № 31. Ст. 1109.

10. Про затвердження Положення про використання повітряного простору України : постанова Кабінету Міністрів України від 06.12.2017 № 954. Офічійиий вісник України. 2017. № 101. ст. 3118.

11. Про затвердження Авіаційних правил України «Загальні правила польотів у повітряному просторі України»: наказ Державної авіаційної служби України та Міністерства оборони України від 06.02.2017 р. № 66/73. Офіиійний вісник України. 2017. № 45. Ст. 1416.

12. Про створення об'єднаної цивільно-військової системи організації повітряного руху України : постанова Кабінету Міністрів України від 19.07.1999 № 1281. Офіuійний вісник України. 1999. № 29. ст. 1484.

13. Про затвердження політики власності Державного підприємства обслуговування повітряного руху України: наказ Міністерства інфраструктури України від 18.12.2018 № 641. Інформаційно-правові системи Ліга: Закон. URL: https://ips.ligazakon.net/document/FN049111?an=1.

УДК 342.951:004.5

DOI https://doi.org/10.32844/2618-1258.2019.6.25

ВЕСЕЛОВА Л.Ю.

\section{АДМІНІСТРАТИВНО-ПРАВОВІ ЗАХОДИ У СФЕРІ ЗАБЕЗПЕЧЕННЯ КІБЕРБЕЗПЕКИ}

У статті констатується, що адміністративно-правові засоби забезпечення кібернетичної безпеки реалізуються відповідним адміністративно-правовим механізмом забезпечення кібернетичної безпеки, низкою адміністративно-правових норм і здійснюваних на їх основі спеціальних юридичних дій у цій сфері. Своєю чергою адміністративно-правові заходи забезпечення кібернетичної безпеки $\epsilon$ діяльною частиною нормативно визначених адміністративно-правових засобів. Тобто більш широким юридичним терміном $є$ «адміністративно-правові засоби забезпечення кібернетичної безпеки», що реалізуються певними нормативно передбаченими способами й прийомами у практичній діяльності суб'єктів національної системи кібернетичної безпеки. У статті надається класифікація заходів адміністративно-правового забезпечення кібернетичної безпеки. Зазначається, що примусові заходи щодо адміністративно-правового забезпечення кібербезпеки мають бути обов'язково законодавчо унормовані. Зазначається, що без відповідного закріплення примусових заходів щодо адміністративно-правового забезпечення кібербезпеки в акті законодавства як елементу механізму адміністративно-правового забезпечення кібербезпеки вони не можуть бути використані. Аналізуються підходи вчених щодо класифікації заходів адміністративного примусу. Дослідивши теоретичні засади, адміністративно-правові заходи у статті пропонується розглядати за трьома групами: заходи адміністративного стягнення (штраф, конфіскація, виправні роботи тощо); заходи адміністративного припинення (особисте затримання, позбавлення спеціального права тощо); адміністративно-попереджувальні заходи (огляд, перевірка документів, вимога припинення окремих дій тощо). Зазначається, що кожна із груп заходів має своє специфічне призначення, але одночасно наділені також спільними характеристиками, що визначаються державно-владним характером та є обов'язковими для виконання. Автор статті зазначає, що в межах до-

(C ВЕСЕЛОВА Л.Ю. - кандидат юридичних наук, доцент кафедри адміністративної діяльності поліції (Одеський державний університет внутрішніх справ) 